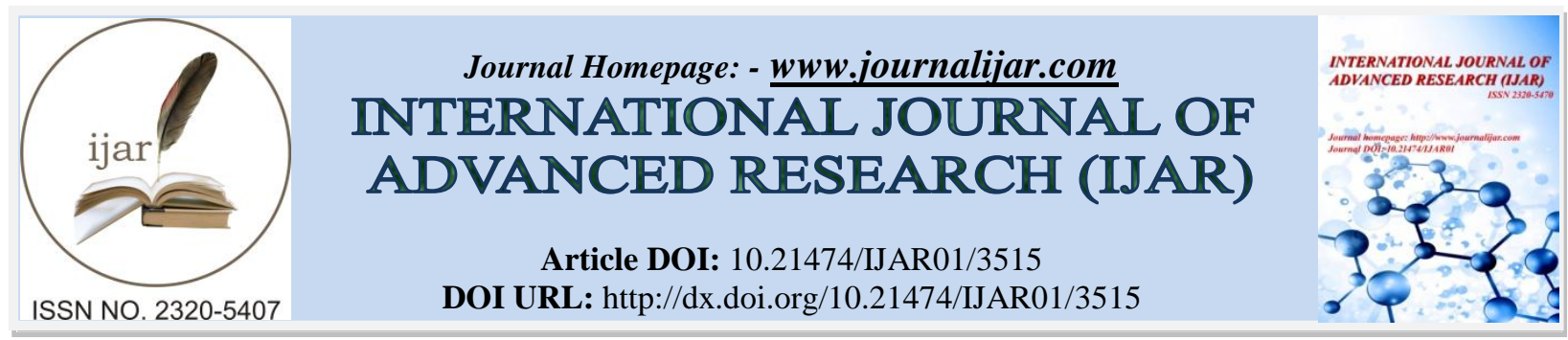

RESEARCH ARTICLE

\title{
DEVELOPMENT AND STANDARDIZATION OF MENTAL MATURITY SCALE FOR PRE-SERVICE STUDENTS.
}

\section{Mrs. T. Jayagandhi ${ }^{1}$ and Dr. M. Suganthi ${ }^{2}$.}

1. Research Scholar, Lecturer, DIET, T.Kallupatti, Madurai-625702.

2. Assistant Professor, Alagappa University College of Education, Karaikudi - 630003.

\section{Manuscript Info}

Manuscript History

Received: 15 January 2017

Final Accepted: 16 February 2017

Published: March 2017

\section{Key words:-}

Tool construction, Standardization, mental maturity, pre-service teachers.

\begin{abstract}
The present study is designed to construct the mental maturity scale for pre-service teachers. The Mental maturity scale was developed and standardized by administering it on 55 randomly selected pre-service teachers of Madurai district and conducting item analysis to eliminate the inconsistent items in a tool. The final form of mental maturity scale consists of 42 items classified into 7 sections namely mental health, self-awareness, problem solving, cognitive self management, multiple intelligence, social attitude and emotional maturity. All the items of mental maturity scale are Likert type with five point rating.
\end{abstract}

Copy Right, IJAR, 2017,. All rights reserved.

\section{Introduction:-}

Maturity implies putting away of childish things and regarding oneself as an adult ready to shoulder responsibilities that develop upon one in general in worldly affairs. It is related to the kind of personality one has developed. It is also concerned with the extent to which one is able to think act for oneself. A mature person is highly socialized and independent. He has built up a set of values for himself which guide his actions and behavior consistently. Emotional stability, intensity, social adjustment, professional interests and life aspirations go on increasing with the process of attaining maturity. A mature person is expected to understand things of importance and be aware of his rights and duties. A mature person does not act impulsively and does not waste time in the world of his own imagination.

Mental maturity is generally believed that a person with average intelligence acquires mental maturity between 13 and 15 years of age and a brilliant one gets it within 16 and 25 years of age. By the term mental maturity we mean mature ideas. The criteria of mental maturity are:

- The power of independent judgement without being guided by one's caste, class, traditions, or some influential person.

- Readiness to fulfill one's responsibility and duty.

- To analyse a situation objectively without being influenced by one's sentiments.

- To reach a right decision when confronted with complex situations.

- To decide issues with a spirit of give and take and not to overlook future consequences when overpowered by emotions.

The ultimate aim of teacher education is to prepare effective teachers who are capable of bringing about the desired behavioural changes in pupils. The quality of teaching is determined by the quality of teaching learning process 
made in the classroom situations. So the pre-service teachers must improve mental maturity. Then only they can improve the quality of school education. So the investigator decided to construct and standardize the mental maturity scale for pre-service teachers.

\section{Objectives:-}

- To construct the mental maturity scale for Pre-service teachers.

- $\quad$ To standardize the mental maturity scale for Pre-service teachers.

The Mental maturity scale was constructed to measure the skill of mental maturity of Pre-service teachers. The steps followed for its construction and standardization are as follows:

1. Planning

2. Preparation of Preliminary form

3. Pre-tryout

4. Editing

5. Pilot study

6. Item Analysis

7. Preparation of final form

\section{Planning:-}

During planning it was decided to prepare the statements with reference to mental health, self-awareness, problem solving, cognitive self management, multiple intelligence, social attitude and emotional maturity.

\section{Preparation of Preliminary form:-}

The investigator developed the preliminary form of mental maturity scale for pre-service teachers with 70 simple, clear and concise statements for better understanding. Care was taken to avoid ambiguity and repetition in the statements. At the end of each statement, five graded options were given namely. "Strongly agree", "Agree", "Undecided", "Disagree" and "Strongly disagree" having scores 5,4,3,2 and 1 for positive statements and 1,2,3,4 and 5 for negative statements. The investigator classified the statements of preliminary form of mental maturity scale under different sections namely mental health, self-awareness, problem solving, cognitive self management, multiple intelligence, social attitude and emotional maturity.

\section{Pre-tryout:-}

The Preliminary form of mental maturity scale for pre-service teachers was given to 10 teacher educators for their observation and criticism regarding the clarity of statements, appropriateness of the language and the pattern against each statement. Based on their suggestions, the developed research tools were further edited.

\section{Editing:-}

Soliciting the responses of the teacher educators approached at the pre-tryout stage, the editing of the developed research tool was completed. On the basis of criticisms and suggestions of the experts involved, 5 statements were rejected and 65 statements were retained.

\section{Pilot study:-}

For the standardization of the constructed tool, the investigator conducted a pilot study. The constructed tool was administered on 55 randomly selected pre-service teachers studying in DIET, Madurai district. The pre-service teachers were instructed to mark their responses for all the statements of mental maturity scale. Further, they were given assurances that their responses would be used only for research purpose. They were also convinced that their responses would be kept confidential. There was no time limit, but the pre-service teachers took 40 to 50 minutes for giving responses to all the statements of the tool. The responses of pre-service teachers were scored according to the positive or negative nature of statements.

\section{Item Analysis:-}

The investigator used item whole correlation to find out ' $r$ ' values. The item having ' $r$ ' values between 0.35 and 0.65 were retained and the other items were rejected. In the final mental maturity scale, 42 items were retained with positive (32) and negative (10) items. 
Table 1:- Item whole correlation for mental maturity scale.

\begin{tabular}{|c|c|c|c|}
\hline Item. No. & $\mathbf{r}^{\prime}$ Value & Remarks & Item number in mental maturity scale \\
\hline 1 & 0.514170691 & Retained & 1 \\
\hline 2 & 0.314755875 & Rejected & \\
\hline 3 & 0.286770536 & Rejected & \\
\hline 4 & 0.050745996 & Rejected & \\
\hline 5 & 0.470296511 & Retained & 2 \\
\hline 6 & 0.425550036 & Retained & 3 \\
\hline 7 & 0.031395406 & Rejected & \\
\hline 8 & 0.651537975 & Retained & 4 \\
\hline 9 & 0.407366878 & Retained & 5 \\
\hline 10 & 0.534555892 & Retained & 6 \\
\hline 11 & 0.29546716 & Rejected & \\
\hline 12 & 0.230880957 & Rejected & \\
\hline 13 & 0.403585573 & Retained & 7 \\
\hline 14 & 0.593752854 & Retained & 8 \\
\hline 15 & 0.374328076 & Retained & 9 \\
\hline 16 & 0.057879103 & Rejected & \\
\hline 17 & 0.071226087 & Rejected & \\
\hline 18 & 0.565367422 & Retained & 10 \\
\hline 19 & 0.427614185 & Retained & 11 \\
\hline 20 & 0.565141707 & Retained & 12 \\
\hline 21 & 0.448991621 & Retained & 13 \\
\hline 22 & 0.405815439 & Retained & 14 \\
\hline 23 & 0.398733473 & Retained & 15 \\
\hline 24 & 0.405408639 & Retained & 16 \\
\hline 25 & 0.486430903 & Retained & 17 \\
\hline 26 & 0.465951917 & Retained & 18 \\
\hline 27 & 0.466950226 & Retained & 19 \\
\hline 28 & 0.526462766 & Retained & 20 \\
\hline 29 & 0.205382954 & Rejected & \\
\hline 30 & 0.592337104 & Retained & 21 \\
\hline 31 & 0.227275458 & Rejected & \\
\hline 32 & 0.327493852 & Rejected & \\
\hline 33 & 0.345958714 & Rejected & \\
\hline 34 & 0.405605684 & Retained & 22 \\
\hline 35 & 0.389239412 & Retained & 23 \\
\hline 36 & 0.326807346 & Rejected & \\
\hline 37 & 0.402965297 & Retained & 24 \\
\hline 38 & 0.41060083 & Retained & 25 \\
\hline 39 & 0.490937768 & Retained & 26 \\
\hline 40 & 0.402597389 & Retained & 27 \\
\hline 41 & 0.38383348 & Retained & 28 \\
\hline 42 & 0.453662757 & Retained & 29 \\
\hline 43 & 0.632777954 & Retained & 30 \\
\hline 44 & 0.44091366 & Retained & 31 \\
\hline 45 & 0.630455047 & Retained & 32 \\
\hline 46 & 0.522314852 & Retained & 33 \\
\hline 47 & 0.232215771 & Rejected & \\
\hline 48 & 0.110913755 & Rejected & \\
\hline 49 & 0.245486829 & Rejected & \\
\hline 50 & 0.553845456 & Retained & 34 \\
\hline 51 & -0.077709067 & Rejected & \\
\hline 52 & 0.149146801 & Rejected & \\
\hline
\end{tabular}




\begin{tabular}{|c|c|c|c|}
\hline 53 & -0.181720204 & Rejected & \\
\hline 54 & 0.357098688 & Retained & 35 \\
\hline 55 & 0.627565969 & Retained & 36 \\
\hline 56 & 0.595588646 & Retained & 37 \\
\hline 57 & -0.00274471 & Rejected & \\
\hline 58 & 0.179960345 & Rejected & \\
\hline 59 & 0.41938927 & Retained & 38 \\
\hline 60 & 0.52725274 & Retained & 39 \\
\hline 61 & -0.079612746 & Rejected & \\
\hline 62 & 0.389781483 & Retained & 40 \\
\hline 63 & 0.381927493 & Retained & 41 \\
\hline 64 & 0.285229562 & Rejected & \\
\hline 65 & 0.397709655 & Retained & 42 \\
\hline
\end{tabular}

Table 2:- Section-wise Distribution of Items of Mental maturity Scale.

\begin{tabular}{|c|c|c|c|c|c|}
\hline Sl. No. & Dimensions & $\begin{array}{c}\text { Item number } \\
\text { in mental } \\
\text { maturity scale }\end{array}$ & $\begin{array}{c}\text { Positive } \\
\text { items }\end{array}$ & Negative items & $\begin{array}{c}\text { Total number } \\
\text { of items }\end{array}$ \\
\hline 1. & Mental health & $1-8$ & $1,5,6$ & 8 & 4 \\
\hline 2. & Self-awareness & $9-18$ & $9,10,13,14,15$ & 18 & 6 \\
\hline 3 & Problem solving & $19-23$ & $19,20,21,22$ & 23 & 5 \\
\hline 4. & $\begin{array}{c}\text { Cognitive self- } \\
\text { management }\end{array}$ & $24-29$ & $24,25,27,28$ & 26 & 5 \\
\hline 5. & Multiple intelligence & $30-38$ & $30,34,37,38$ & 35 & 5 \\
\hline 6. & Social attitude & $39-54$ & $39,40,41,42,43,44,45$, & $46,50,54$ & 10 \\
\hline 7. & Emotional maturity & $55-65$ & $55,56,59,60,65$ & 62,63 & 7 \\
\hline
\end{tabular}

Preparation of the final form:-

After item analysis the final form of mental maturity scale for pre-service teachers was prepared with 42 retained items.

Reliability and validity of the tool:-

Split-half reliability coefficient of mental maturity scale was determined on the basis of scores of 55 randomly selected pre-service teachers. In the split-half method, the tool was divided into two equivalent halves and for these two halves half-test reliability coefficient was found using Karl Pearson's coefficient correlation formula. From the half-test reliability coefficient, whole-test reliability coefficient was estimated by using Spearman Brown Prophecy formula.

Whole-test reliability coefficient, Split half-test and Guttman Split-Half Coefficient of mental maturity scale for preservice teachers were $0.797,0.754$ and 0.744 respectively. Hence the developed tool was reliable.

On the basis of opinions of experts the items of mental maturity scale were structured. Hence the developed tool has face validity and content validity.

\section{Conclusion:-}

The education of the students largely depends on their teachers. It is important that pre-service teachers who are the future teachers of the country must possess the skill of mental maturity. This will inculcate the pre-service teachers to be efficient. The great teacher should be necessarily equipped with knowledge, skills and competencies. The teacher should be properly enlightened, educated through proper training and develop sense of responsibility and love towards his profession and with rapid expansion of primary education both in number and extent, the teacher must come out of teacher educational institutions with great perfection in teaching competencies and allied aspects. 


\section{References:-}

1. Prof. Chaube, S.P, (2003). Developmental Psychology. Hyderabad-500095; Neelkamal Publications Pvt. Ltd.

2. Mangal, S.K. (2001). General Psychology. New Delhi-110016: Sterling Publishers Pvt.Ltd.

3. Dandapani, S. (2004). A textbook of Advanced educational Psychology. New Delhi-110002; Anmol publications Pvt.Ltd.

4. Prakash, S., Rev.Dr.Amaladoss Xavier, S. (2014). Edu Track. Hyderabad-500095; Neelkamal Publications Pvt. Ltd.

5. Areekkuzhiyil, Santhosh. (2011) Approaches to Instructions: A manual for professional Practitioners. New Delhi; Neelkamal Publications Pvt. Ltd.

6. NCTE, (2004), Competency based and commitment Oriented Teacher Education for Quality school Education, Pre-service and In-service Programme, New Delhi: NCTE

7. Dr. Dutt, B.S.V., Dr. Digumarti Bhaskara Roa. (2001). Empowering primary teachers; Discovery Publishing House, New Delhi-110002. 